\title{
Mandible lymphoma: an aggressive osteolytic lesion
}

\author{
Camila S. Oliveira', Matheus H. A. de Lima', Felipe D'Almeida Costa², Danyel Elias da Cruz Perez ${ }^{3}$, \\ Talita Maira Bueno da Silveira da Rocha ${ }^{4}$ and Fabio Abreu Alves ${ }^{1,5^{*}}$ (D)
}

\begin{abstract}
Background: Diffuse large B-cell lymphoma (DLBCL) is the most common type of non-hodgkin's lymphoma. In oral cavity represents approximately $2 \%$ of all malignancies.

Case presentation: This report describes a rare mandibular involvement of DLBCL. A 56 year-old man was referred for evaluation of left mandible pain. In the anamnesis, the patient informed to be treating tooth pain in lasting 6 months. On oral evaluation, an intense mobility of the left mandibular second molar and a swelling in posterior left mandible were observed. Computed tomography showed a large osteolytic lesion affecting both mandibular body and ramus. An incisional biopsy was performed and according to histopathological and imumnohistochemical features, DLBCL was diagnosed. The treatment consisted of 8 cycles of R-CHOP and adjuvant radiotherapy. He is asymptomatic after 6 years.
\end{abstract}

Conclusion: This case showed a rare bone presentation of DLBCL and such tumor should be considered as differential diagnosis of osteolytic lesion of the mandible.

Keywords: Hodgkin's lymphoma, Mandible tumors, Oral lymphomas, Osteolytic lesion

\section{Background}

Lymphoma is a group of lymphoid system cancer, which is classically divided in Hodgkin's lymphoma (HL) and Non-Hodgkin's lymphoma (NHL). These tumors affect individuals of any age. However, HL are more common in younger individuals, whereas NHL affects, more frequently, adults from the fifth decade of life [11]. Diffuse large B-cell lymphoma (DLBCL) is the most common subtype of NHL.

Approximately $24 \%$ of NHL affect extra-nodal sites, which occur outside the lymphoid system, and $5 \%$ of these have bone involvement $[1,10]$. In the mandible, NHL account for $8 \%$ of all malignant tumors of this bone, and about $0.6 \%$ of all NHL. Due to its low

\footnotetext{
* Correspondence: falves@accamargo.org.br

'Stomatology Department, A.C. Camargo Cancer Center, Rua Professor

Antonio Prudente, 211, Liberdade, São Paulo, SP 01509-010, Brazil

${ }^{5}$ Stomatology Department, School of Dentistry, São Paulo University, São

Paulo, Brazil

Full list of author information is available at the end of the article
}

frequency, associated with unspecific symptoms, clinical signs, and radiographic features, such tumors are frequently misdiagnosed [9]. The aim of the present study was to describe a rare case of DLBCL affecting the mandible and discuss its main differential diagnosis.

\section{Case presentation}

A 56-year-old man was referred for diagnosis of a swelling and pain in left side of jaw with 6 months of duration. The medical history showed extraction of the third molar 4 months ago. On extra-oral examination was observed a discrete asymmetry in mandible angle region. No abnormalities were noted on intraoral examination. Panoramic radiography, performed previously to the tooth extraction, revealed an osteolytic lesion in the left mandibular ramus (Fig. 1a). Moreover, decreasing of bone density and loss of the limits of the mandibular canal were observed. After 4 months of the exodontia, because of pain reported by the patient, a new panoramic radiography was performed. Radiographic

(c) The Author(s). 2020 Open Access This article is licensed under a Creative Commons Attribution 4.0 International License, which permits use, sharing, adaptation, distribution and reproduction in any medium or format, as long as you give appropriate credit to the original author(s) and the source, provide a link to the Creative Commons licence, and indicate if changes were made. The images or other third party material in this article are included in the article's Creative Commons licence, unless indicated otherwise in a credit line to the material. If material is not included in the article's Creative Commons licence and your intended use is not permitted by statutory regulation or exceeds the permitted use, you will need to obtain permission directly from the copyright holder. To view a copy of this licence, visit http://creativecommons.org/licenses/by/4.0/. 

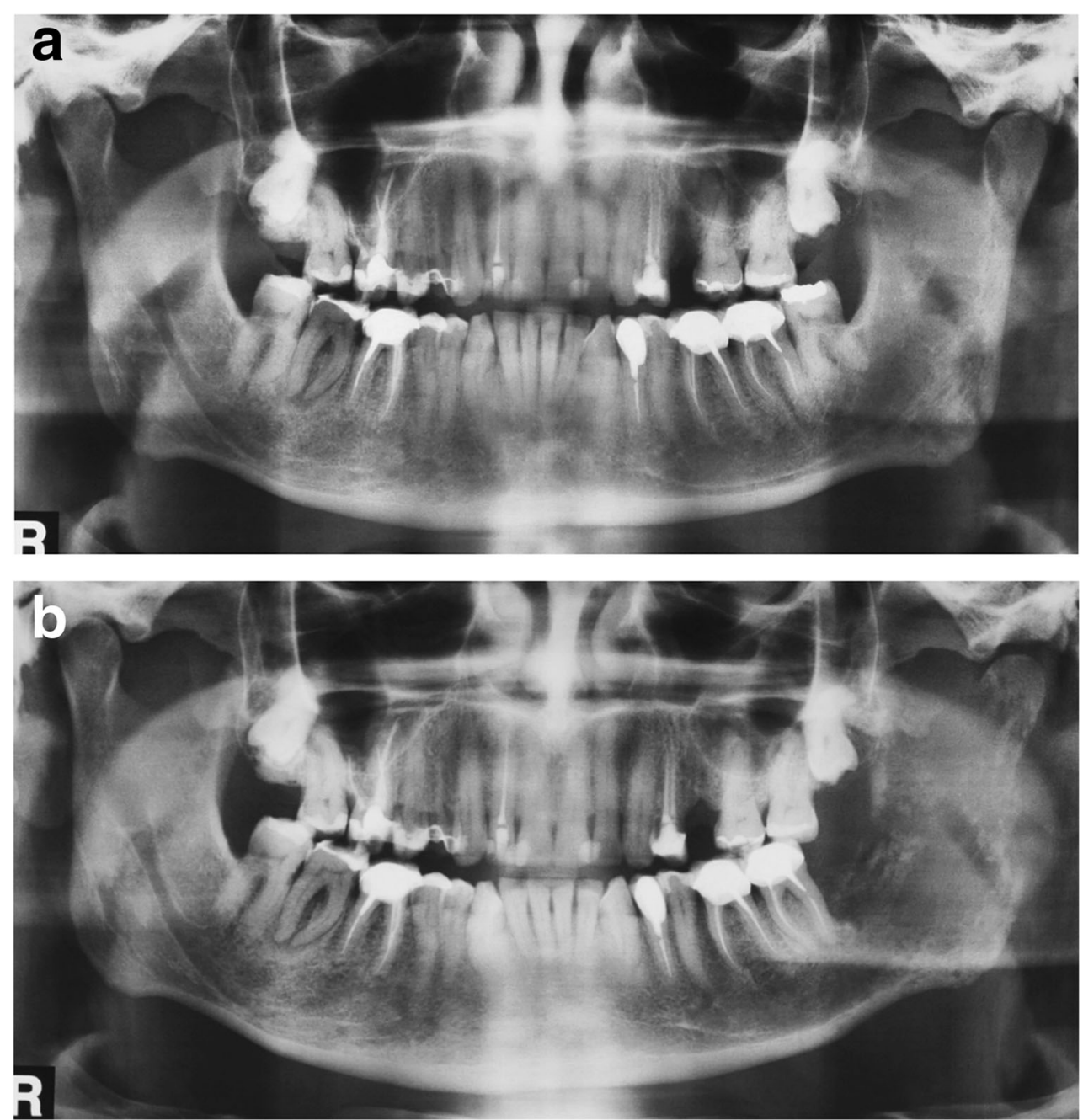

Fig. 1 a Panoramic $x$-ray showing bone changes in the left ramus of the mandible. b Panoramic $x$-ray showing the fast evolution of the lesion with bone destruction of mandibular ramus

examination showed severe destruction of the mandibular ramus, suggesting a pathological bone fracture (Fig. 1b).

The main diagnosis hypotheses were a malignant tumor, probably an osteosarcoma, and metastasis. An incisional biopsy was performed. Microscopically, there is diffuse infiltration of large pleomorphic cells, which presented frequent atypical mitoses and binucleation, suggesting a lymphoid pattern malignancy. An immunohistochemical panel was performed, which revealed cells positive for CD20, CD10, BCL6, and Ki-67 (around 80\% of the cells). The tumor cells were negative for CD3, Bcl-2, MUM1, and Cyclin (Fig. 2). Thus, the final diagnosis was DLBCL, with immunofenotype similar to the germinative center.

PET-CT was performed to plan the treatment. There were hypercaptation in left mandible (12.4 SUV) and clavicle (8.1 SUV) (Fig. 3a and b).
The patient underwent 8 cycles of chemotherapy with the $\mathrm{R}-\mathrm{CHOP}$ scheme and adjuvant 3D radiotherapy with a total dose of $36 \mathrm{~Gy}$ in the left mandible field. The patient is asymptomatic after 6 years of the diagnosis (Fig. 4).

\section{Discussion}

To classify NHL as a bone primary disease, it is important to exclude any other evidence of visceral or lymphatic involvement and no other site lesion at least 6 months after diagnosis. Oral lymphomas account for $2.5 \%$ of all cases of lymphomas, and when there is involvement of soft tissues, salivary gland, cheeks, paranasal sinuses, and gingiva are the most affected sites $[1,10]$. Bone involvement of the jaws is rare and occurs more frequently in the maxilla than in the mandible $[1,4,6,10]$. Primary NHL of the 

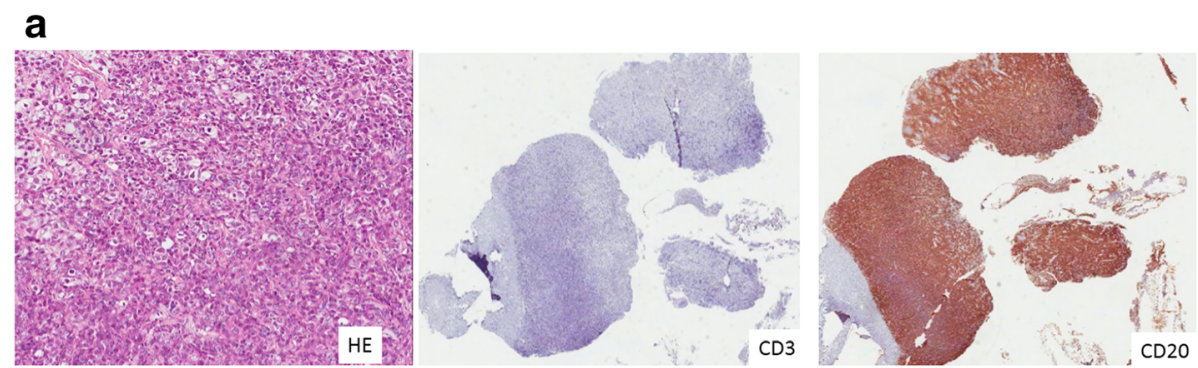

\section{b}

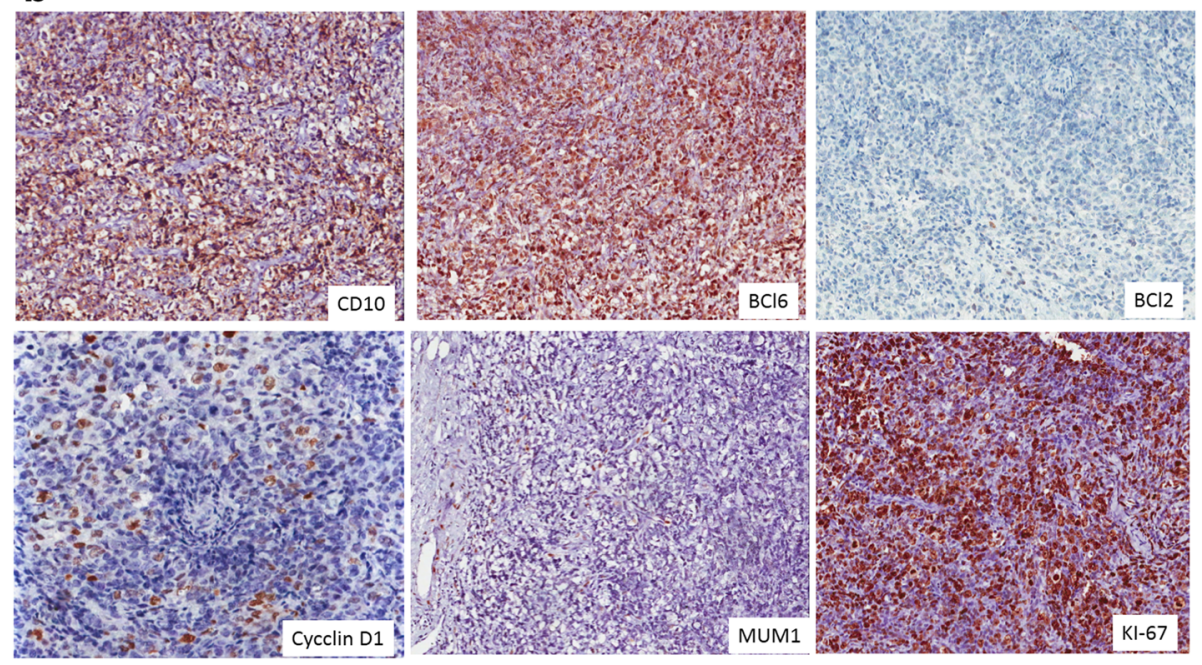

Fig. 2 a Diffuse proliferation of large and atypical lymphoid cells (HE staning). Immunohistochemical showing negativity for CD3 and strong positivity for CD20. b. Immunohistochemistry was positive for CD10 and BCL6 and negative for BCL2, Cyclin D1 and MUM-1. The proliferative index was high (Ki-67)
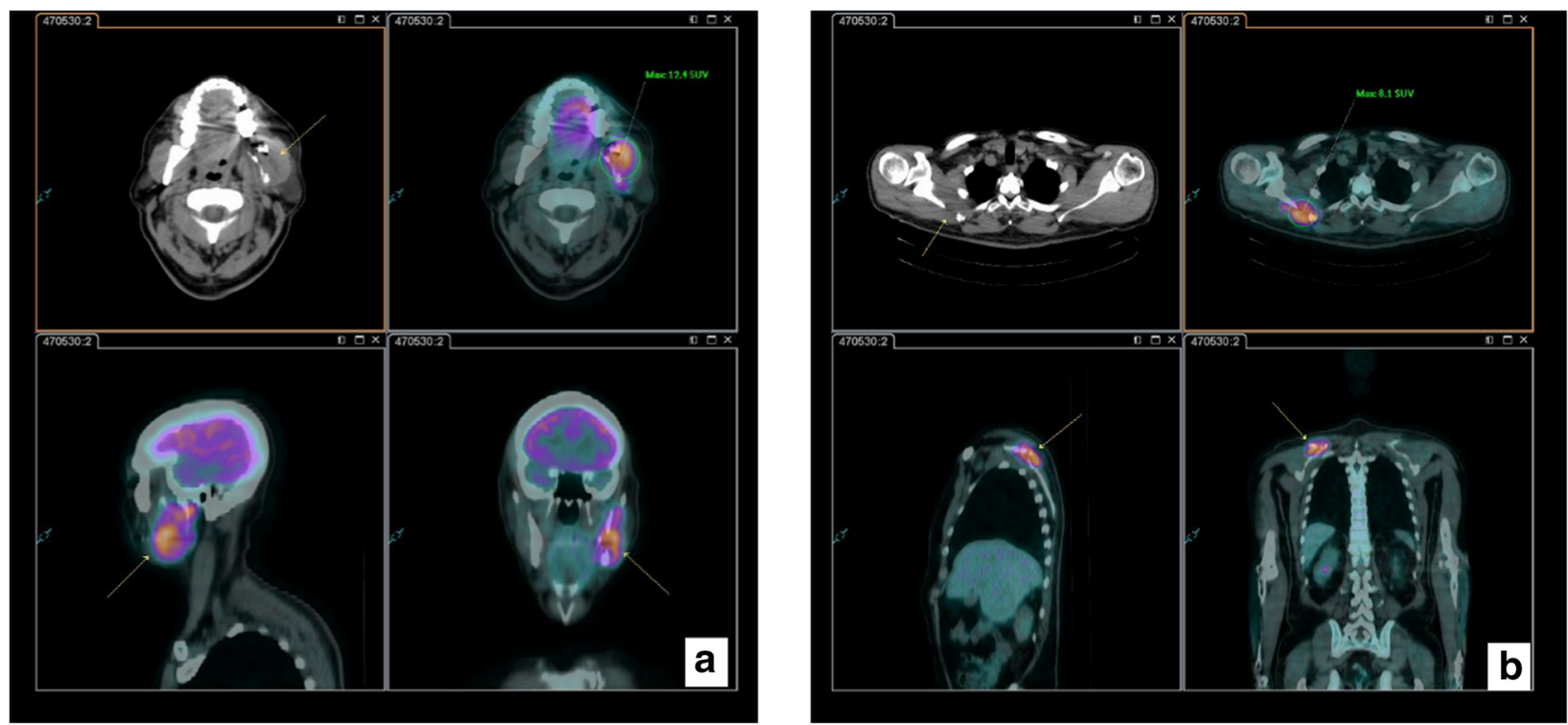

Fig. 3 a PET-CT with uptake of 12.4 SUV in the left mandible. b PET-CT with uptake of 8.1 SUV in the clavicle right 


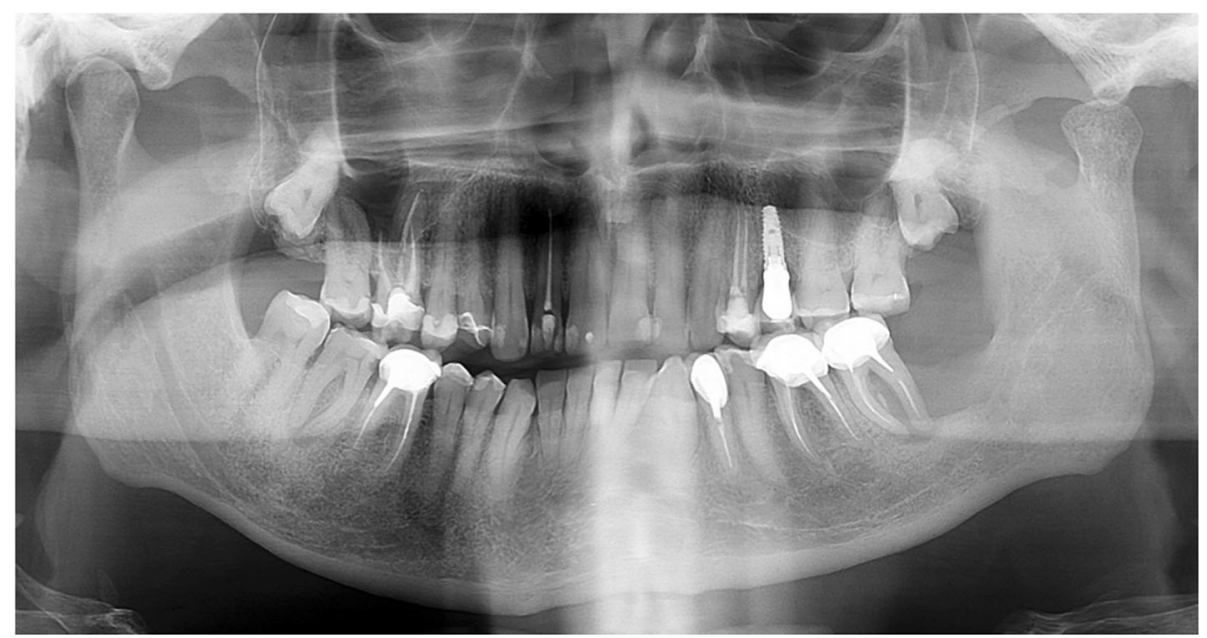

Fig. 4 Panoramic radiography of control (6 years after the diagnosis)

mandible represents $0.6 \%$ of all NHL, $5 \%$ of all bone NHL, and $8 \%$ of all mandibular tumors $[1,7,12]$. It presents predilection for more men, occurring more frequently in the sixth decade of life $[6,7]$. The present case affected exclusively bones (mandible and clavicle) in a 56-YO man.

Mandible lymphomas may be misdiagnosed as an odontogenic infection or tumor. Consequently, delay in the diagnosis is commonly observed, with a mean time of 2 to 3 months $[1,4,5,8,10-12]$. The most frequent clinical manifestations are localized bony growth, dental mobility, pathological fracture, pain and neurological disturbance $[1,2,6,7,10,12]$. In the current case, the patient had a history of tooth extraction 4 months previous to the diagnosis, with pain appearing as the chief complain. Radiographic examination usually shows diffuse bone destruction, alveolar bone resorption, periodontal disease, and loss of cortical definition or enlargement of the mandibular canal [1-3, 6, 7, 10, 12]. In this case, an extensive osteolytic lesion and pathological condyle fracture were the main findings. Furthermore, loss of the definition of the mandibular canal was also observed. All features are strongly suggestive of a malignant neoplasm.

Treatment for jaw lymphomas usually consists of a combination of chemotherapy and radiation therapy. The prognosis of these lesions is favorable when localized diseases. However, maxillary lymphoma has a higher rate of recurrence when compared to other sites of involvement [3]. The present patient was submitted to chemotherapy and radiotherapy (only in mandibular fields), with no disease relapse after 6 years.

In conclusion, radiolucent lesions with ill-defined margins associated with pain are important features of a malignant neoplasm, including DLBCL. Thus, the radiologist should keep in mind that, although DLBCL is rare, it may occur in the mandible. Additionally, despite of rarity, the DLBCL should be included in the differential diagnosis of lesions with such features.

\section{Abbreviations \\ DLBCL: Diffuse large B-cell lymphoma; HL: Hodgkin's lymphoma; NHL: Non- Hodgkin's lymphoma}

\section{Acknowledgements \\ Not applicable.}

Authors' contributions

Diagnosis- Drs. Alves, Perez and Costa, Patient's treatment- Dr. Rocha, DataDr. Oliveira and de Lima, Drs. Alves, Perez and Costa - major contributor in writing the manuscript. Manuscript preparation- All authors read and approved the final manuscript.

\section{Funding}

Not applicable.

Availability of data and materials

Not applicable.

Ethics approval and consent to participate Not applicable.

Consent for publication

All authors have approved the final article.

\section{Competing interests}

All authors state there is no conflict of interest.

\section{Author details}

${ }^{1}$ Stomatology Department, A.C. Camargo Cancer Center, Rua Professor Antonio Prudente, 211, Liberdade, São Paulo, SP 01509-010, Brazil.

${ }^{2}$ Department of Anatomic Pathology, A.C. Camargo Cancer Center, São Paulo, Brazil. ${ }^{3}$ Oral Pathology Unit, School of Dentistry, Universidade Federal de Pernambuco, Recife, Brazil. ${ }^{4}$ Oncology Departament, A.C. Camargo Cancer Center, São Paulo, Brazil. ${ }^{5}$ Stomatology Department, School of Dentistry, São Paulo University, São Paulo, Brazil. 
Received: 7 February 2020 Accepted: 6 May 2020

Published online: 25 May 2020

\section{References}

1. Adouani A, Bouguila J, Jeblaoui Y, Ben Aicha M, Abdelali MA, Hellali M, et al. B-cell lymphoma of the mandible: a case report. Clin Med Oncol. 2008;2: 445-50.

2. Bugshan A, Kassolis J, Basile J. Primary diffuse large B-cell lymphoma of the mandible: case report and review of the literature. Case Rep Oncol. 2015;8: $451-5$.

3. Djavanmardi L, Oprean N, Alantar A, Bousetta K, Princ G. Malignant nonHodgkins's lymphoma (NHL) of the jaws: a review of 16 cases. J CranioMaxillofac Surg. 2008:36:410-4.

4. Kini R, Sasha A, Naik V. Diffuse large B-cell lymphoma of mandible: a case report. Med Oral Patol Oral Cir Bucal. 2009:14:e421-4.

5. Kobler P, Borcic J, Filipovic Zore I, Nola M, Sertic D. Primary non-Hodgkin's lymphoma of the oral cavity. Oral Oncol Extra. 2005;41:12-4.

6. Kolokotronis A, Konstantinou N, Christakis I, Papadimitriou P, Matiakis A, Zaraboukas T, et al. Localized B-cell non-Hodgkin's lymphoma of oral cavity and maxillofacial region: a clinical study. Oral Surg Oral Med Oral Pathol Oral Radiol Endod. 2005;99:303-10.

7. Longo F, De Maria G, Esposito P, Califano L. Primary non-Hodgkin's lymphoma of the mandible report of a case. Int J Oral Maxillofac Surg. 2004;33:801-3.

8. Müller AM, Ihorst G, Mertelsmann R, Engelhardt M. Epidemiology of nonHodgkin's lymphoma (NHL): trends, geographic distribution, and etiology. Ann Hematol. 2005;84:1-12.

9. Nayak PB, Desai D, Pandit S, Rai N. Centroblastic variant of diffuse large Bcell lymphoma: case report and review of literature. J Oral Maxillofac Pathol. 2013;17:261-5.

10. Okahata R, Shimamoto H, Marutani K, Tomita S, Nakatani A, Kishino M, Kakimoto N, et al. Diffuse large B-cell lymphoma of the mandible with periosteal reaction: a case report. Oral Surg Oral Med Oral Pathol Oral Radiol. 2014;117:228-32.

11. Pazoki A, Jansisyanont P, AND Ord R. Primary non-Hodgkin's lymphoma of the jaws. J Oral Maxillofac Surg 2003;61:112-117.

12. Steinbacher DM, Dolan RW. Isolated non-Hodgkin's lymphoma of the mandible. Oral Oncol Extra. 2006;42:187-9.

\section{Publisher's Note}

Springer Nature remains neutral with regard to jurisdictional claims in published maps and institutional affiliations.

Ready to submit your research? Choose BMC and benefit from:

- fast, convenient online submission

- thorough peer review by experienced researchers in your field

- rapid publication on acceptance

- support for research data, including large and complex data types

- gold Open Access which fosters wider collaboration and increased citations

- maximum visibility for your research: over $100 \mathrm{M}$ website views per year

At BMC, research is always in progress.

Learn more biomedcentral.com/submissions 